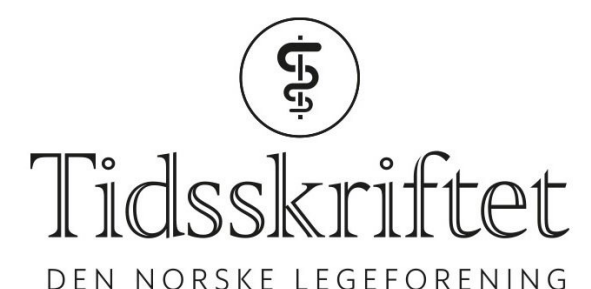

\title{
Grønn sone
}

INTERVJU

IRENE THORESEN RØNOLD

E-post: irene.thoresen.ronold@tidsskriftet.no

Da Kine Jordbakke fikk turnusplass i Seljord, forsøkte hun å bestikke en kompis til å ta den i stedet. Nå jobber hun dag og natt for å beskytte de om lag 3 ooo innbyggerne i kommunen mot covid-19.

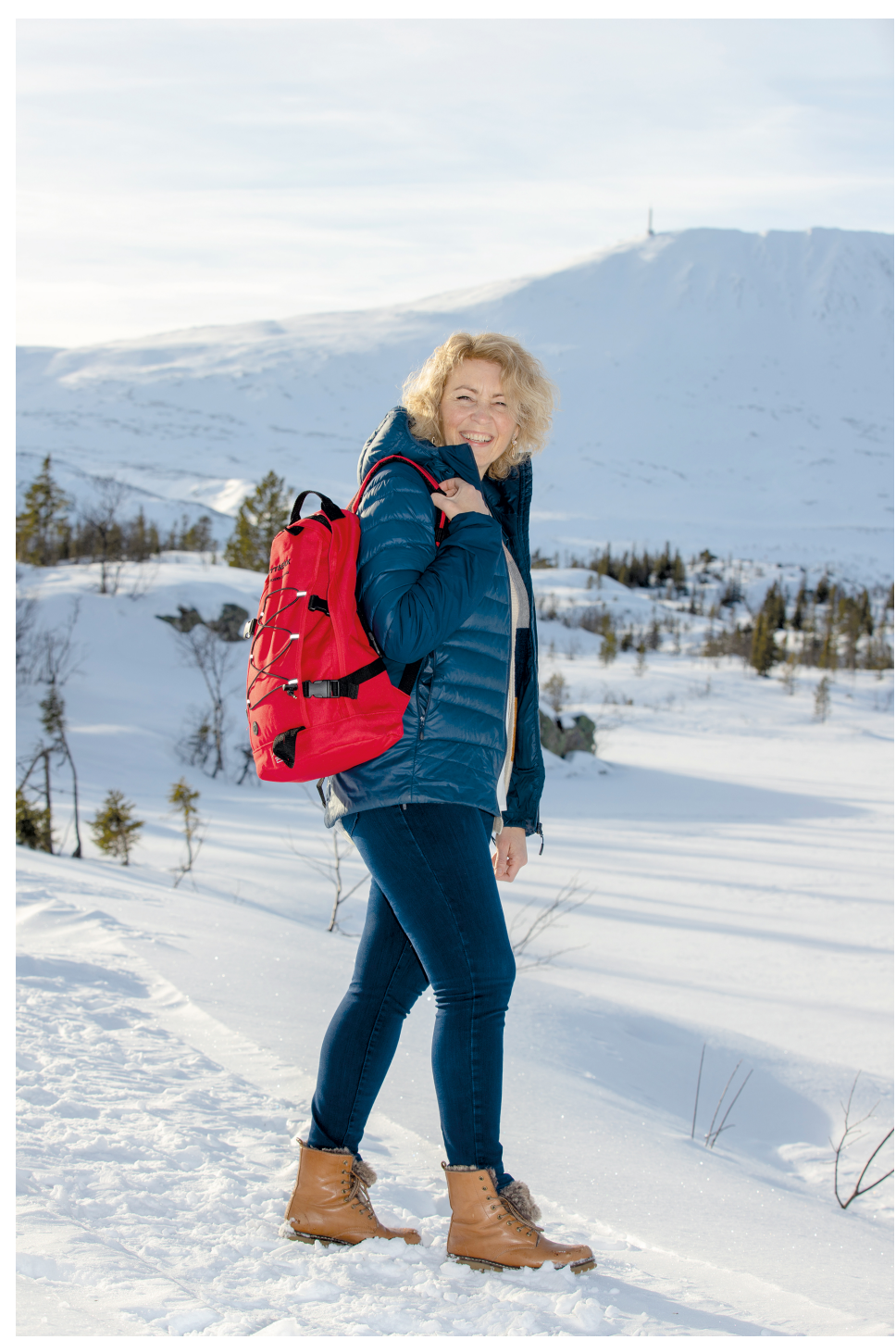

Foto: Britt Eriksen, Foto Telemark 
Vi er bare noen få minutter ut i et intervju via videokonferanse på Teams når telefonen til kommuneoverlegen ringer.

- Nei, du, jeg sitter i et møte. Sorry.

Sånn har det vært siden covid-19-pandemien begynte. Hun kunne knapt avslutte en telefonsamtale uten at det ringte en ny. Det har vært arbeidsdager på 16-18 timer, fra hjemmekontor, med tre barn som skulle ha hjemmeskole og en hel kommune med litt under 3 ooo innbyggere som skulle ha luftveislegevakt og isolater og smittevernutstyr og vedtak med hjemmel i smittevernloven.

Kine Jordbakke avslutter telefonsamtalen og vender seg mot skjermen.

- Hva var det jeg sa?

- At du er redd for å være for streng.

- Ja! Og så er jeg redd for å være for slepphendt. Jeg gjorde en avveining og tenkte: «OK. Jeg tror jeg kan leve bedre med å være for streng enn med å være for slepphendt.»

Seljord kommune var én av flere telemarkskommuner som bestemte seg for å innføre karantenepåbud. I en periode på flere uker måtte alle som reiste fra Oslo, Viken og andre steder med mye smitte, i karantene dersom de kom til Seljord. Det ser ut til å ha betalt seg: Når vi skriver mai 2020, har Seljord kommune kun hatt én registrert smittet. Og den personen bor ikke engang i kommunen, han er bare folkeregistrert der, forteller Jordbakke.

- Det kan ha vært ... Fader å det ringer!

Jeg tror jeg kan leve bedre med å være for streng enn med å være for slepphendt

Hun tar telefonen, sier kjapt at hun ikke kan prate og legger på før hun fortsetter resonnementet:

- Det kan ha vært flaks. Det er jo ikke så veldig mange mennesker som bor her. Og vi vet at vi har hatt noen smittede her, men det var da testkriteriene var strengere og vi ikke kunne teste alle med symptomer.

\section{Før pandemien}

Forrige gang vi snakket sammen, var det andre tider. Det var den første helgen i februar, det var strålende vintersol og worldcup i Telemark, og på Gaustablikk høyfjellshotell ble det holdt kurs i akuttmedisin. Det var fylt med leger i ullgenser og skibukse, unge leger og eldre leger, kvinner og menn. De hentet kaffe og frukt fra samme fat, slo av en prat og håndhilste på hverandre. Ingen forsøkte å måle antall meter mellom hver kursdeltaker.

\section{Kine Jordbakke}

Født på Bærum sykehus 1973

Oppvokst på Blommenholm med tre søsken og alltid 1-2 hunder

Ungdomsarbeider for Norges Røde Kors i det tidligere Jugoslavia etter krigen på Balkan,

1997

Studerte medisin ved Royal College of Surgeons, Dublin 1997-2003

Turnusplass på Notodden sykehus og i Seljord kommune

Jobbet i Seljord kommune siden 2004

Akuttoverlege på sykehuset Telemark 2015-16

Spesialist i allmennmedisin

Prosjektleder Akuttkjeden i Telemark siden 2016

Kommuneoverlege i Seljord kommune siden 2018

Samboer med Torbjørn og mamma til Maren, Herman og Nora 
De snakket om været og føret og gledet seg til skitur i lunsjen, alle bortsett fra Kine Jordbakke. Hun ledet Gaustablikkkurset sammen med Mads Gilbert og hadde bestemt seg for å la ski være ski (litt kjedelig når det var så fint vær) for å snakke med Tidsskriftet om sitt nyeste faglige hjertebarn.

De siste årene har Kine Jordbakke vært leder for et prosjekt som skal gi Telemark landets beste akuttkjede. I 2016 bestemte Telemark at akutte tjenester skulle være et satsningsområde, men de slet med å få med seg kommunene. Den jobben gikk til Jordbakke, som i tillegg til å være kommuneoverlege hadde erfaring fra akuttmottak.

- Jeg tok et år på sykehus som en del av spesialiseringen. Da så jeg at det var et stort gap mellom inne og ute. De på sykehuset vet lite om hva som skjer i førstelinjen, og tror - litt fordomsfullt noen ganger - at det ikke blir gjort noe særlig bra. Det var jeg opptatt av å gjøre noe med, sier hun.

- Hvordan så akuttkjedene i Telemark ut før dette prosjektet begynte?

- Vi så at det var veldig mye variasjon. Det var ikke noe system. Legevaktene var ulikt bemannet, utstyret var forskjellig, det var forskjellige åpningstider på legekontorene. Det finnes ingen legevaktforskrift som sier hvordan det egentlig skal være.

\section{En sekk, en app, et skjema}

Sykehuset Telemark, ambulansetjenesten, AMK-sentralen, legevakter, fastleger, kommunene i Telemark og andre aktører har vært involvert i prosjektet. De ansatte i hjemmetjenestene har det vært særlig viktig å involvere. Det er de som ser pasienten først.

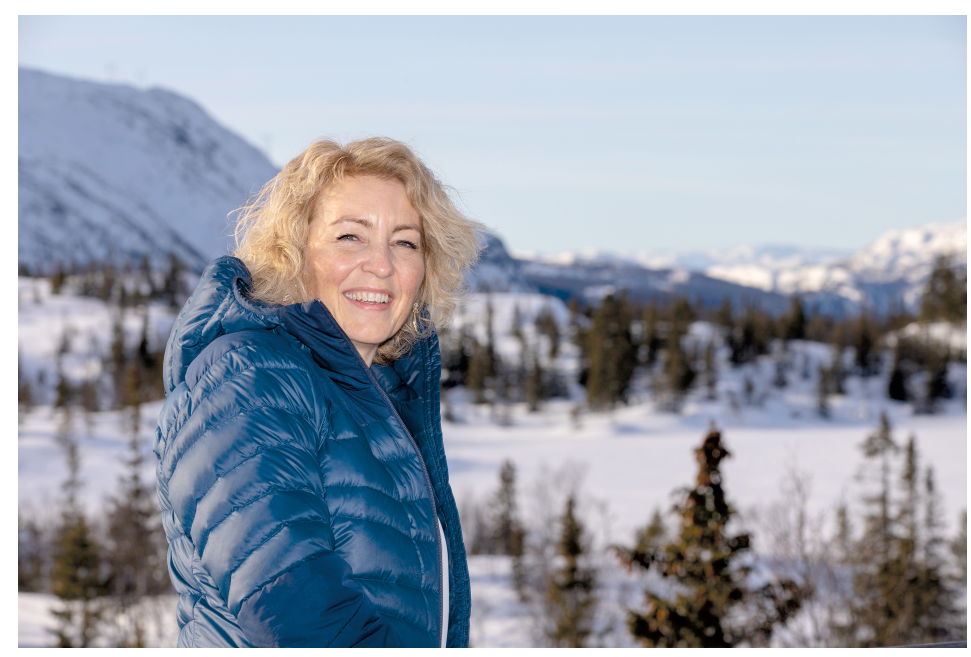

Arbeidet med å strømlinjeforme prosessen har gitt tre håndfaste endringer: en sekk, en app og et skjema. Sekken er knallrød, gis til ansatte i hjemmetjenesten og inneholder utstyr som gjør at de kan ta vitale mål. I appen finnes det flytskjemaer som forteller hvordan ulike pasienter skal behandles - ett for hjertepasienter, ett for slag, og - etter pandemien - ett for covid-19. Så er det skjemaet. Dette skal følge pasienten og fylles ut for hvert nye stopp pasienten tar - hos hjemmesykepleier, på legevakt og på sykehus.

Jeg er veldig opptatt av at alle er like viktige og like mye verdt

Målsettingen er at alle skal få så lik behandling som mulig, uansett hvor de er og hvem de blir møtt av.

Selv om det er vanskelig å måle nøyaktig hva en god akuttkjede er, ser prosjektet ut til å ha vært vellykket. Så vellykket, faktisk, at det er nevnt i nasjonal helse- og sykehusplan. En evaluering av prosjektet viste blant annet at de ansatte i hjemmetjenesten satte pris på prosjektet og følte seg mer kompetente nå. Fastlegene var litt mer skeptiske. De var redde for merarbeid.

- Hva synes du om at hjemmetjenesten er de som har tatt prosjektet best imot?

- Jeg synes det er utrolig kult. Nå snakker alle sammen på en annen måte. Hjemmetjenesten 
får bestille ambulanse. Det fikk de ikke før. Nå bruker de ISBAR-kommunikasjonsmodellen og melder inn på en strukturert måte.

- Hvem meldte inn før?

- Nei, da måtte de ofte via noen. Enten legevakta, eller den mest erfarne sykepleieren på vakt. Nå kan en fagarbeider i helsetjenesten ringe inn og bestille ambulanse. Det er veldig morsomt.

Hun tar sats.

- Jeg er veldig opptatt av at alle er like viktige og like mye verdt. Man møter stadig vekk, ofte i leddet etter deg, en slags skepsis nedad. Hvis man har jobbet på sykehus, har man en tendens til å tenke at det er der pasienten bor. Men de bor hjemme. Og de som har sett dem mest, er hjemmetjenesten og førstelinjen i kommunene. De kjenner dem best, så det er veldig viktig å involvere dem.

\section{Matpakker i postkassa}

Dette kan vi si om Kine Jordbakkes motivasjon for å bli lege: Hun har alltid vært opptatt avå hjelpe folk. Hun er usikker på om det er en sannhet eller om det har blitt det, men hun mener å huske at hun tidlig på barneskolen puttet matpakker i postkassa med påskriften «Til Afrika».

- Jeg skulle redde verden. Jeg og en venninne solgte kaker og hadde basarer fra vi var bitte små, fordi vi skulle redde barna i Afrika.

Moren var bare 19 år og noen måneder unna å være russ da Kine Jordbakke ble født. Kines farmor reagerte med å kaste ut leieboerne sine og lot den lille familien flytte inn hos seg. Der ble de boende, i generasjonsbolig på Blommenholm i Sandvika.

- I starten var det mest farmor som oppdro meg, mens mamma og pappa utdannet seg.

- Det kan ikke ha vært lett å få barn i så ung alder?

- Nei. Men jeg vet ikke om vi snakket så veldig mye om det. Mamma sa alltid bare «ikke gjør som meg», humrer Kine Jordbakke.

De var unge, de tok henne med overalt. Kine, eldst av fire søsken, har vært vant til liv og røre helt fra hun var liten. Kanskje er det derfor hun har blitt, ifølge både venner og samboer, «ekstremt sosial».

- Jeg var med på alle fester. Ikke sånn at det var skadelig, jeg måtte legge meg, men jeg var alltid med. Når man er ung og har barn, slutter man gjerne ikke å være med vennene sine av den grunn, sier hun, og husker plutselig en historie:

- En gang glemte de meg faktisk i hotellresepsjonen da de var på påsketur med venner. De hadde satt seg i beltebil og var på vei innover Hardangervidda da de kom på: «Å nei! Ungen!».

Hun ler.

- De vennene har vært viktige for meg opp gjennom livet. Og de er fortsatt en sånn god vennegjeng. Det er fine forbilder.

\section{- Du kan gjøre mye hjemme også}

Da hun endelig kom inn på medisinstudiet som 24-åring, var det Dublin som ble studiestedet. I en periode måtte hun ha tre sommerjobber for å dekke skolepengene. Det var det verdt.

Når det er sagt: kommuneoverlege i Seljord var aldri planen da Kine Jordbakke studerte, leste og festet med studenter fra mer enn 50 nasjoner. Hun skulle ut i verden. Hun husker fortsatt skuffelsen hun kjente da hun fikk turnusplass i Seljord.

- Jeg foreslo å betale en turnuslege på Notodden sykehus mange tusen for å bytte 
turnusplass med meg. Han hadde turnus i Øvre Eiker. Det er heller ikke verdens navle. Og han hadde slekt i Seljord. Men han ville ikke bytte, ler hun.

Det er vanskelig å forklare nøyaktig hva som skjedde, eller hvorfor det snudde. Men da hun kjørte med flyttelasset sitt på vei til Seljord, rundet hun en sving, og rundt der lå det et vann.

- Jeg følte på en måte at jeg hadde vært her før. Og det var veldig hyggelig her.

Den ene tilfeldigheten tok den andre, slik det ofte gjør i livet. En av de første var at hun trengte en ny sofa til turnusboligen. Slik traff hun på sønnen til han som eide møbelbutikken i bygda. De ble først venner, så kjærester og samboere. I dag har de tre barn.

Så fikk hun en sjef, damen som var kommunelege før henne, Elisabeth Swensen.

- Jeg husker at jeg sa til henne: «Jeg skal ut og redde verden. Jeg skal jobbe ute». Hun sa: «Det er mange du kan redde her hjemme òg» Det har jeg tenkt mye på. Du kan gjøre mye hjemme også.

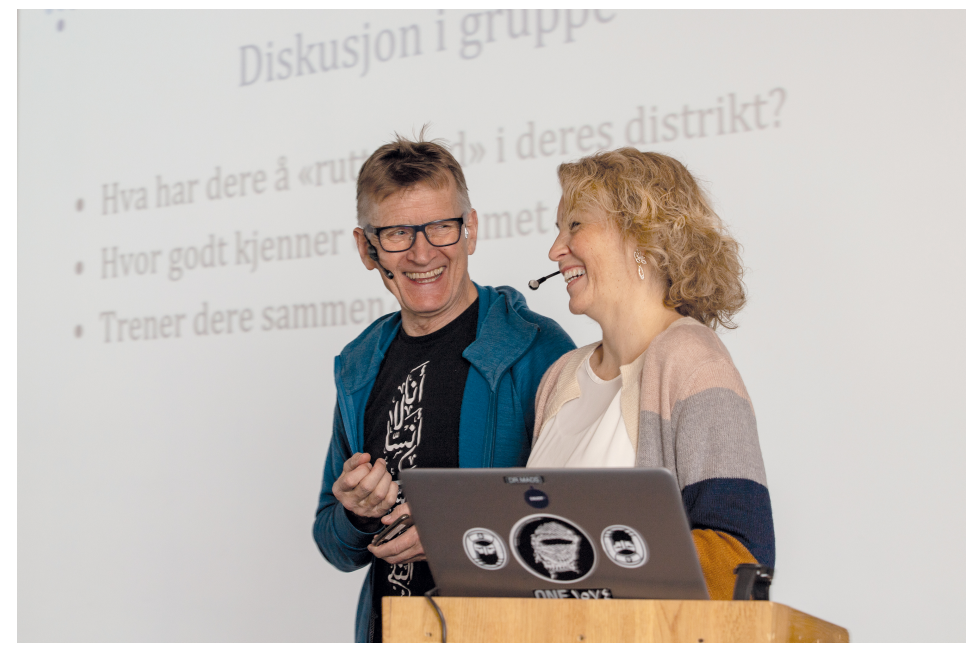

\section{Grønn sone}

Jobben viste seg å være mer spennende enn hun trodde.

- Når du bor på en liten plass, får du muligheten til å studere et helt samfunn. Du ser alle sjiktene. Du ser forbindelser og sammenhenger. Det er veldig spennende - selv om prisen du betaler er å aldri være helt komfortabel med å gå i joggebukse på butikken. Som kommuneoverlege på en liten plass får du ikke være helt anonym.

- Nå har jeg vært fastlege i 15 år. Mine pasienter kjenner jeg veldig godt. Det er så koselig. Det tar lengre og lengre tid å få dem ut av kontoret, men det er en del av det å være fastlege. I snitt varer mine fastlege-pasient-forhold i syv år. Det er det få andre i helsetjenesten som kan vise til, tror jeg.

De siste ukene har alt handlet om å holde covid-19-smitten unna Seljord. Det har vært mye å finne ut av. Hvordan skal man skrive ut pasienter? Hvordan skal man passe på at man ikke får smitte med inn på sykehus, eller fra sykehus til sykehjem? Hvordan skal man behandle døende pasienter i kommunen?

-Vi har fått på plass mye. Vi er vant til å samarbeide, blant annet på grunn av akuttkjedeprosjektet, og dette har gitt oss et fortrinn i Telemark.

Når du bor på en liten plass, får du muligheten til å studere et helt samfunn

Tidlig i pandemien regnet Jordbakke seg fram til at kommunen kun hadde smittevernutstyr nok til å holde i en uke. Det var én av mange grunner til at de valgte å innføre karantenepåbud. Mangel på utstyr føltes for utrygt.

- Føler du at du har stått litt alene i det?

- Ja. Alle kommuneoverleger har det. I starten fikk vi litt kred, fordi vi var så flinke. Men når vi begynte å innføre egne bestemmelser - som karantenepåbudet - da fikk vi på pukkelen 
fra fylkesmannen og Helsedirektoratet og beskjed om at vi ikke kunne det. Jeg har fint kunnet leve med det å heller være for streng enn for slepphendt. Men vi har stått veldig alene. Med et enormt ansvar! Liv og død! Sånn føles det, sier hun, og legger til:

- Heldigvis er ikke dette et veldig farlig virus. For de aller fleste går det fint å bli smittet av covid-19. Likevel er det ikke noe gøy å føle seg ansvarlig for at den ene som ikke tålte det, fikk det. Eller for at alle på sykehjemmet ble smittet. Det er et stort ansvar. Og jeg tror ikke sentrale myndigheter skjønner hvordan det er å stå i det.

Nå, når Norge har begynt å åpne opp, er utfordringen å holde trykket oppe. Både på kontoret, i kommunen og i befolkningen. Det kan være vrient å forstå hvorfor kommuneoverlegen fortsatt insisterer på at de skal sitte hver for seg og ikke kjøpe smågodt på butikken. Men enn så lenge er de trygge i sin lille, grønne sone, der ingen er registrert smittet.

- Alt i alt ser det ut til at Seljord har klart seg ganske bra?

Hun smiler lurt over Teams.

- Ja. God kommuneoverlege, vet du.

Publisert: 15. juni 2020. Tidsskr Nor Legeforen. DOI: 10.4045/tidsskr.20.0475

(C) Tidsskrift for Den norske legeforening 2020. Lastet ned fra tidsskriftet.no 